\title{
The Impact of Creative Teaching Approach on Reducing Boredom in the Teaching Process
}

Marijana Radeljić', Hazim Selimović2, Siniša Opićs , Nermin Mulaosmanović ${ }^{2}$ and Zehrina Selimović ${ }^{2}$

'Elementary school "Stjepan Radić" Imotski

2Faculty of Education, University of Travnik

${ }^{3}$ Faculty of Teacher Education, University of Zagreb

\section{Abstract}

Creativity, as one of the key factors of success, should primarily be represented in educational institutions in all segments of life, ranging from pre-school to higher education institutions. Starting from the assumption that simple, monotonous, and uninteresting classes are one of the main obstacles to the successful education of a student, in this paper we will explore the creative approach in the teaching process in order to reduce boredom in classrooms.

The sample consisted of 134 participants. There were 66 participants in the experimental group and 68 participants in the control group. The students in the experimental group were in the classrooms where the creative approach was used, while the students of the control group attended the classes in which the traditional approach of teaching was used.

The research was conducted based on a designed research model. The instrument was distributed before applying the experimental model and after its application.

The aim of this study was to examine whether the introduction of creativity into the teaching process influences its efficiency, and at the same time reduces boredom. Analysis of the final measurement results showed that the level of students' boredom in the experimental group was reduced comparing to the level of students' boredom in the control group. What's more, our findings showed that the application of creative models within the teaching process had a positive effect on reducing boredom.

Keywords: creativity, creative teacher, efficient / contemporary teaching process, boredom. 


\section{Introduction}

Education is the foundation of every society and without quality education there is no successful society. In order to maintain successful education, it is necessary to innovate teaching process through changes that will contribute to the successful aacquiring of teaching content. When it comes to successful teaching process, it is inevitable to talk about creativity, because creativity is the basis of a successful teaching process.

Nowadays, most authors emphasize that creativity is the ability to create something new, original, and valuable, that is, a surprise which is not stereotypical not stereotypical nor comes out comes out of the usual ways of thinking (Sternberg, 2005). Gallager (1986, according to Vizek, Vidović et al., 2003) defined creativity as a mental process in which a person creates new ideas or products or combines existing ideas and products with a new approach.

Creativity is one of the qualities of the personality that allows each individual to realize themselves to their full potential. Furthermore, creativity includes the use of divergent thinking, finding multiple answers to the same question, freeing emotions, humour, and suppressing fear and boredom (Dubovicki, 2016).

It is certain that creativity is the key to success in all segments of life, and so in education where a successful teaching process is the result of a creative approach to learning. "The study of creativity today is dominant for the purpose of education, where the school as a place of systematic development is considered as one of the basic predispositions for the development of creativity from the creative potential of an individual" (Simel \& Gazibara, 2013, p. 189).

Today's way of life demands an independent, responsible, and creative individual, and therefore, education is asked to develop creative and critical thinking in students. Students connect creativity with positive, interesting, and fun things, and mostly with subjects that include the production of practical work. Furthermore, students believe that creativity in school should be given more room, not only in subjects related with practical work, but in other subjects as well. (Perić, 2015).

Through creativity, students create new ideas, organise information, and think about the concept of questions. The basic purpose of creativity is that the child understands the world around him/her and that $\mathrm{s} /$ he is not afraid of the idea (Bowkett, 2007). It is the creativity that creates new ideas and it is well-known that ideas change the world. "There is no innovation without creativity, the world needs a young generation with new ideas, the generation that can change and improve existing ideas" (Simel \& Gazibara, 2013, p. 190).

In order to develop creativity, it is necessary that there is a creative teacher who will develop this creativity with students. The creativity of the teacher is the predisposition for the development of students' creativity and the qualities that one can acquire and cultivate (Bognar \& Bognar, 2007).

Zuliani, Matić and Keteleš (2015) emphasise that success with student creativity depends on their predispositions and personal affinity to progress, but also on the 
teacher's ability in the field of creativity, with particular reference to the preparedness and organization and formation of the teaching process.

The teacher can maintain the development of students' attitude and creativity, teach the students creative methods in his/her subject and encourage an open atmosphere in the classroom for creative solving of problems (Starko, 2010).

The teacher has an unlimited range of creativity to implement in his/her reaction to the students. Creativity is a serious student activity; however, it does not mean that it cannot be associated with humour. Thus, Čudina-Obradović (1990) recommends more games that encourage the development of creativity, as well as Bognar (1991) and Milijević (1989) who recommended games for teaching process that skilfully combine humour and creative activities for students.

Lack of creativity leads to boredom or monotony, which is often the case in our schools. "Boredom is a state of unpleasant feelings, lack of stimulation and low physiological stimuli" (Pekrun, Goetz, Daniels et al., 2010, p. 532). If a student finds classes boring, we cannot expect his/her success in it. Besides the everyday pressure to achieve in school, boredom is a syndrome that is certainly the biggest problem of students, as well as a significant cause of disturbances in the teaching process.

Andrilović and Čudina (1988) emphasise that boredom is a state (of the organism) caused by external stimuli that are excessively rare or excessively monotonous, besides, its long duration causes the search for a more interesting source of stimulation.

Boredom can be a serious motivational blockade interfering with learning (Pekrun, Frenzel et al., 2002). Everyone knows that students often feel boredom during class. According to Pekrun (2007), boredom is produced when students consider the subject matter irrelevant, and/or when they perceive their control over the situation is either too large or too small.

Daschmann et al. (2011) cite monotony in class as the main cause of boredom in learning, i.e., the students' assessment that the subject is irrelevant, as well as lack of clear goals.

If a student finds a class annoying, and especially if a teachers' support is lacking, it is expected that rebellion will arise in the process of acquiring teaching content and, therefore, a failure in learning process as well.

Kolak and Majcen (2011) mentioned a worryingly high intensity of boredom.

Teachers should provide an atmosphere in today's schools that will encourage students to work creatively. Teachers should maintain it by talking, by planning together with students, by asking unusual questions or ideas, by accepting students' initiatives (Cowley, 2006).

Such a school represented the rationale of this research. The goal of this study is to determine the influence of the creative approach in teaching as an experimental model (which was carried out in the experimental group) to reduce boredom in the teaching process in relation to the classical teaching method carried out in the control group. 
Based on the research goal, the following hypotheses have been defined:

The creative teaching approach will have a positive impact on reducing boredom in the teaching process. Respondents in the experimental group are expected to have a lower level of boredom compared to the control group.

Creative teaching is expected to reduce the level of boredom among both female and male students. Creative teaching is expected to reduce the level of boredom among all students, regardless of students' marks in English.

\section{Methodology}

\section{Procedure}

The study on the impact of creative teaching on reducing boredom in teaching process was conducted in the school year 2016/2017. In order to carry out the research, consent was obtained from the principal of the primary schools where the research was conducted. Prior to the survey, the respondents were familiar with the significance of the research itself and the procedure of its implementation. The respondents were also informed that the research is used only for scientific purposes. At the beginning of the research and before the introduction of the experimental model in the experimental group, groups were harmonised based on the results of the initial measurements in the groups. Equalization of the groups was based on the level of boredom. The students filled in the questionnaire at the beginning of the school year, both from the experimental and the control group. After that, the students from the experimental group were subjected to treatment in English classes that was performed by a special methodology characterized by a creative approach, while the students from the control group were exposed to the classic approach.

The experiment was carried out in such a way that the English language classes were filled with verbal and visual stimuli, flash cards, stories, and conversations with pupils. Various didactic games were used which were adapted to the educative content. Rules were defined at the very beginning. Pupils brought their favourite toys to class so that they could be used in the learning process. The tasks which a child could not perform or did not feel comfortable doing were carried out using favourite toys which were used to "repeat" statements, respond to questions, dance, and sing. Thus, the pupils were led to express themselves through drama and puppetry. Pair work and groupwork were used, which stimulated task performance and created interactive and cooperative relationship.

One rather current teaching method that was used was TOTAL PHYSICAL RESPONSE (TPR). This method is based in the coordination between language and physical movement. The control group was exposed to the reproduced teaching content by means of traditional frontal teaching. The experiment was carried out in the academic year 2016/2017. The pupils were given a questionnaire at the end of the teaching process.

The research was conducted during the whole school year so that the respondents of both groups were re-investigated in May 2017. 


\section{Sample}

The study that we conducted on the role of creativity in teaching process included 134 students of the fourth grade of the Stjepan Radić elementary school in Imotski $(\mathrm{N}=134)$, in the school year $2016 / 2017$. There were 66 female participants $(49.3 \%)$ and $68(50.7 \%)$ male participants out of the 134 students.

We performed the Chi-square test in order to examine the uniformity of the sample with regard to gender and their English language marks. The value of $\chi^{2}=0.030$ with a significance level of 0.863 shows that the sample is gender-uniform because there is no statistically significant difference between females and males. The experimental group consisted of $66(49.3 \%)$ students, where $33(50 \%)$ are male students and 33 (50 \%) are female students. The control group included 68 (50.7\%) students, 35 (51.5\%) were male and 33 (48.5\%) female participants.

In the experimental group there are $4(6.1 \%)$ students with the passing mark 2 (satisfactory), 21 (31.8\%) students with the passing mark 3 (good), 23 (34.8\%) students with the passing mark 4 (very good) and 18 (27.3\%) students with the passing mark 5 (excellent).

In the control group there are $12(17.6 \%)$ students with the passing mark 2 (satisfactory), 29 (42.6\%) students with the passing mark 3 (good), 15 (22.1\%) students with the passing mark 4 (very good) and $12(17.6 \%)$ students with the passing mark 5 (excellent).

The results of the Chi-square test $\left(\mathrm{X}^{2}=1.684 ; \mathrm{p}=0.194\right)$ for students with the "very good" school mark/success $(\chi 2=1,280 ; p=0,258)$ for students with the "good" school mark and $(\chi 2=1,200 ; p=0,273)=3,267 p=0,07)$ for students with the "sufficient" school mark shows that the sample is equal to the success of the experimental and control group because there is no statistically significant difference between the students when it comes to their school mark / success in the previous school year.

\section{Instrument}

In the instrument, the researchers used a five-point Likert-type estimation scale. In the study, the ISC-S Inventory "Assessment of Boredom in Teaching Process" was applied (Milijević, 1984, p. 13).

Respondents (students) expressed their degree of agreement and disagreement with the items through the scale. The first group of questions, which is at the beginning of the questionnaire, intends to collect basic socio-demographic data on students involved in the research. Demographic data include gender, class, school, and passing grade. A brief explanation of the purpose of the instrument, the content of the problem being investigated, and the way of responding to the claims were included in the questionnaire. The instrument consists of 18 questions (claims). The respondents expressed their agreement using a 5-point Likert scale from 1 to 5: 1 (never); 2 (seldom); 3 (about half the time ); 4 (usually) and 5 (always).

All of the questions in the instrument are negatively formulated, e.g. Teaching is mostly boring or learning is not interesting to me. 
Therefore, responses with lower values (1 and 2) imply a better state, while responses with higher values (4 and 5) imply a worse state or greater boredom.

Students provided data in two identical questionnaires: in the first, which was conducted at the beginning of the school year (initial survey), and in the second, conducted at the end of the school year (final survey).

The survey was anonymous, and after completion of the final survey, the questionnaires were paired for each student (initial questionnaire with the final one) in order to analyse the changes in the answers. The reliability of the questionnaire was tested by the internal consistency method according to the Alpha model (Reliability Analysis). The entire 18-part scale (claims, items) shows the value of Cronbach alpha 0.983 in the initial survey and 0.984 in the final survey.

\section{Results of the study}

In order to test the efficiency of the experimental model it is necessary to examine the equivalence of the experimental and control group at the initial measurement. Mann-Whitney's $U$ test results show $(U=1821,000 ; z=-1.884 ; p=0.060)$ that the difference between the groups is not statistically significant.

In order to make the first analysis of the results based on 18 claims from the students of the experimental and control group in the initial survey, it was necessary to determine whether the distribution of the response to individual assertions is similar to normal distribution. The examination was made using the Kolmogorov-Smirnov test. The obtained $\mathrm{p}$ value of 0.043 shows that none of the distributions is similar to normal distribution, which means that in the analysis of these distributions (assertions) using parametric tests (t-tests for dependent samples) is not allowed. However, only nonparametric tests (Wilcoxon Signed Ranks Test) can be used.

In order to reduce the number of items in the questionnaire, we conducted the factor analysis. The factor analysis was conducted twice: once for answers in the initial student survey, the second time for answers in the final student survey. The tests to verify conditions for the implementation of factor analysis were previously carried out as well. The Kaiser-Meyer-Olkin measure of sample adequacy was 0.971 for the initial survey and 0.979 for the final survey.

The Bartlett spherical test showed the following results: $\chi 2=3014,417$ for the initial survey; $\mathrm{df}=153 ; \mathrm{p}<0.001$; and $\chi 2=3172.946 ; \mathrm{df}=153 ; \mathrm{p}<0.001$ for the final survey.

According to the results, it is concluded that there are prerequisites for the implementation of factor analysis. Factor analysis was carried out by calculating the intercorrelation matrix for 18 items (questions, variables) from the questionnaire. The factor extraction was done by the method of the main components, varimax factor rotation, and factor scores calculated for all participants from the experimental group (66 students).

According to the Kaiser-Guttman criterion for determining the significance of factors, the first and only extracted factor was significant, i.e. the structure was a 
single-factor structure. The only factor in the structure indicates $77.5 \%$ of the total analysed variance for the initial survey, and $79.1 \%$ for the final survey.

In Table 1, the matrix of the factor structure is non-rotated (for both factor analysis). The solution cannot be rotated due to the fact that in both cases only one component was separated.

Table 1

The structure matrix for both factor analysis ( $N=66)$

\begin{tabular}{rcc}
\hline Item & $\begin{array}{c}\text { Factor } 1 \text { for the } \\
\text { initial survey }\end{array}$ & $\begin{array}{c}\text { Factor } 1 \text { for the final } \\
\text { survey }\end{array}$ \\
\hline 1. & 0,852 & 0,920 \\
2. & 0,916 & 0,892 \\
3. & 0,891 & 0,897 \\
4. & 0,828 & 0,843 \\
5. & 0,868 & 0,878 \\
6. & 0,877 & 0,839 \\
7. & 0,862 & 0,849 \\
8. & 0,854 & 0,769 \\
9. & 0,838 & 0,886 \\
10. & 0,904 & 0,931 \\
11. & 0,901 & 0,916 \\
12. & 0,877 & 0,889 \\
13. & 0,868 & 0,888 \\
14. & 0,867 & 0,914 \\
15. & 0,910 & 0,916 \\
16. & 0,878 & 0,909 \\
17. & 0,907 & 0,912 \\
18. & 0,937 & 0,941 \\
\hline
\end{tabular}

In order to determine the impact of an experimental model on reducing boredom in teaching process, we compared the results between the initial and final measurements in both groups. Furthermore, we looked for the difference in the agreement about the individual assertions by students from the experimental and control group. They are calculated according to the arithmetic mean and the standard deviation of individual items. The results of the z-test are presented in Table 2.

The average values between 2.08 and 2.74 for the initial survey of the experimental group are presented in Table 2. The results indicted an extremely low mean average for the item 1 (Rolling my eyes, I cannot wait for the class to end), which means that it is the least represented, while item 13 indicated the highest average mean (I want to study, but I cannot) that is most represented. The mean scores from the final survey of the experimental group are presented in Table 2, and they range between 1.86 and 2.44, which is lower than in the initial survey. Lower values indicate that the level of boredom is being decreased. It was noted that this reduction in boredom is noticeable for each item $(2.08>1.86$ for the first assertion, $2.26>2.05$ for the second assertion, etc.). In other words, the impact 
of creative teaching is evident, which obviously created greater interest (motivation) among students and reduced boredom in the teaching process.

The central dispersion of the response of the students from the experimental group is evident for the initial and the final survey. Values of the standard deviations in most variables of initial and final survey indicate that these are not homogeneous. Table 2 also shows a slightly higher dispersion of the response in the final survey in comparison to the initial survey.

Table 2 shows the results of the non-parametric Wilcoxon signed rank-test for the experimental and control group. The results show that in the final survey there were statistically significant changes in the answers of the students from the experimental group in relation to the answers of the same students in the initial survey. This statistically significant reduction in boredom is evident in most of the claims, 15 out of a total of 18 claims. Reduction of boredom in the teaching process was also observed for the claims 6,7 and 8. Still, it is not statistically significant.

The responses of the participants from the control group are presented in Table 2. Since the English language classes in the control group were held in a traditional manner, no significant changes were expected in the final survey in relation to the initial survey.

Table 2

Results of descriptive and inferential statistics for the experimental and control group

\begin{tabular}{|c|c|c|c|c|c|c|c|c|c|c|}
\hline \multirow{2}{*}{ No. } & \multirow{2}{*}{ Items (questions) } & \multicolumn{5}{|c|}{ Experimental group } & \multicolumn{4}{|c|}{ Control group } \\
\hline & & & M & SD & z & $\mathrm{p}$ & M & SD & z & $\mathrm{p}$ \\
\hline \multirow[t]{3}{*}{1.} & Rolling my eyes, I cannot & 1 & 2.08 & 1.00 & & & 2.16 & 1.14 & & \\
\hline & wait for the class to end & & & & -3.500 & 0.00 & & & -2.854 & 0.00 \\
\hline & $\begin{array}{l}\text { Rolling my eyes, I cannot } \\
\text { wait for the class to end }\end{array}$ & $\mathrm{F}$ & 1.86 & 0.87 & & & 2.37 & 1.20 & & \\
\hline \multirow[t]{3}{*}{2.} & Classes are usually boring & 1 & 2.26 & 0.98 & & & 2.88 & 1.23 & & \\
\hline & & & & & -2.858 & 0.00 & & & -1.226 & 0.22 \\
\hline & Classes are usually boring & $\mathrm{F}$ & 2.05 & 0.88 & & & 2.76 & 1.34 & & \\
\hline \multirow[t]{3}{*}{3.} & Teachers tease us with & 1 & 2.52 & 0.88 & & & 2.93 & 1.26 & & \\
\hline & their stories & & & & -2.744 & 0.01 & & & -0.816 & 0.41 \\
\hline & $\begin{array}{l}\text { Teachers tease us with } \\
\text { their stories }\end{array}$ & $\mathrm{F}$ & 2.23 & 1.01 & & & 2.99 & 1.32 & & \\
\hline \multirow[t]{2}{*}{4.} & I daydream in class, and I & 1 & 2.48 & 1.10 & -3.162 & & 2.82 & 1.20 & & \\
\hline & $\begin{array}{l}\text { I daydream in class, and I } \\
\text { set my mind at ease }\end{array}$ & $\mathrm{F}$ & 2.18 & 1.04 & & 0.00 & 2.81 & 1.21 & -0.218 & 0.83 \\
\hline
\end{tabular}


5. When I need to study

I $2.53 \quad 1.20$

$2.79 \quad 1.26$

something, I rather do

something else: clean my

shoes

$-2.419 \quad 0.02$

$-0.392 \quad 0.70$

When I need to study

something, I rather do

something else: clean my

F $\quad 2.27 \quad 1.06$

$2.76 \quad 1.34$

shoes

6. If I'm bored in class, I do

I $2.48 \quad 1.14$

$3.13 \quad 1.33$

not raise my hand, or

participate in any other

way

$-1.4140 .16$

$-0.408 \quad 0.68$

If I'm bored in class, I do

not get involved, I do

not raise my hand, or

participate in any other

F $\quad 2.35 \quad 1.10$

$3.16 \quad 1.15$

way

7. I avoid talking about what I $\quad 2.30 \quad 1.08$ we learn in class

$2.93 \quad 1.25$

I avoid talking about what

we learn in class

F $\quad 2.18 \quad 1.07$

$-1.374 \quad 0.17$

$-1.694 \quad 0.09$

$3.06 \quad 1.34$

8. A teacher who orders

I $2.58 \quad 1.16$

$2.99 \quad 1.20$

students what to do is

actually boring

A teacher who orders

$\begin{array}{ll}-1.270 & 0.20\end{array}$

$-1.8990 .06$

students what to do is

actually boring

F $\quad 2.44 \quad 1.15$

$3.15 \quad 1.24$

9. When I have to dedicate

myself to my studies, I feel

$\begin{array}{lll}\text { I } & 2.47 \quad 1.11\end{array}$

disinterested and bored

When I have to dedicate

myself to my studies, I feel

disinterested and bored

F $\quad 2.23 \quad 1.12$

$\begin{array}{ll}-2.450 & 0.01\end{array}$

$2.99 \quad 1.25$

$-0.243 \quad 0.81$

$3.00 \quad 1.34$

$\begin{array}{llll}\text { 10. Studying is not interesting } & \text { | } & 2.48 & 1.17\end{array}$

for me

$2.94 \quad 1.36$

Studying is not interesting

for me

F $\quad 2.06 \quad 1.06$

$\begin{array}{ll}-4.660 & 0.00\end{array}$

$\begin{array}{ll}-1.000 & 0.32\end{array}$

$2.99 \quad 1.38$

11. Learning is difficult and

I $\quad 2.41 \quad 1.18$

2.91

1.27

does not encourage my

curiosity

Learning is difficult and

does not encourage my

curiosity

$\begin{array}{ll}-3.651 & 0.00\end{array}$

$-1.414 \quad 0.16$

F $\quad 2.11 \quad 1.02$

$2.97 \quad 1.26$ 
12. I hesitate to study

I $\quad 2.59 \quad 1.14$

I hesitate to study

13. I want to study, but I

cannot

I want to study, but I

cannot

14. Classes are boring and I

do not want to participate

in them

Classes are boring and I

$\begin{array}{llll}\text { do not want to participate } & F & 2.23 & 1.08\end{array}$

in them

15. Teaching content is

boring, I study as little as possible

Teaching content is

boring, I study as little as

possible

16. I'm sick of some teaching

content

$-2.5150 .01$

I'm sick of some teaching content

17. When I need to study

a difficult subject, I postpone studying as

much as possible

When I need to study

a difficult subject, I

postpone studying as

much as possible

18. I postpone my studying

until the last minute

I postpone my studying

until the last minute

Boredom in teaching

process-all items

Boredom in teaching

process-all items

$\begin{array}{lllll}F & 2.21 & 0.87 & 2.92 & 1.17\end{array}$
I $\quad 2.48 \quad 1.19$

$-2.263 \quad 0.02$

$2.93 \quad 1.30$

$2.85 \quad 1.30$

F $\quad 2.23 \quad 1.15$

$-1.961 \quad 0.05$

$2.97 \quad 1.31$

$3.04 \quad 1.20$

$-0.853 \quad 0.39$

$3.10 \quad 1.32$

$2.96 \quad 1.29$

$-0.390 \quad 0.70$

$\begin{array}{ll}-1.265 & 0.21\end{array}$

$2.91 \quad 1.28$

$2.96 \quad 1.19$

$\begin{array}{ll}-2.611 & 0.01\end{array}$

$-0.302 \quad 0.76$

$\begin{array}{lll}F & 2.36 & 1.14\end{array}$

$2.94 \quad 1.18$

$2.81 \quad 1.28$

$-2.745 \quad 0.01$

$-1.414 \quad 0.16$

$\begin{array}{lll}\text { F } & 2.26 & 1.09\end{array}$

$2.84 \quad 1.29$

$2.84 \quad 1.30$

$-3.900 \quad 0.00$

$\begin{array}{ll}-0.378 & 0.71\end{array}$

$2.85 \quad 1.31$

$\begin{array}{ll}2.88 & 1.17\end{array}$

$-4.806 \quad 0.00$

$-2.198 \quad 0.03$

In the initial survey of the students in the control group presented in Table 2, the lowest mean score of 2.16 was obtained from item 1 (Rolling my eyes, I cannot wait for the class to end), while the highest mean score of 3.13 was obtained from item 6 (If I'm bored in class, I do not get involved, I do not raise my hand, or participate in any other way). 
In the final survey of the students from the control group, the lowest mean score 2.37 was obtained for item 1 as in the initial survey, and the highest mean score for the final survey was observed for item 6 , same as in the initial survey. A higher mean score was observed from the final survey due to item 8 with an average of 3.15 (A teacher who orders students what to do is actually boring). The coefficients of variation range between $39 \%$ and 53 (ks) \%, in other words, between $36 \%$ and 51 (es) \%, which indicates the non-homogeneous properties of the observed variables. The results gathered from the control group indicated statistically significant changes in the responses of the students from the control group in the final survey in relation to the answers of the same students in the initial survey. The changes are random for 17 claims ( $p>0.05$ ). The change was statistically significant only in case of item 1 and the summarized result for all assertions ( $p>0.05$ ). Such a result was expected, since the teaching approaches in the control group were not changed during the school year, so the students' interest did not change significantly, i.e. their interest in their classes and education has decreased, and their level of boredom has increased.

The research also determined the influence of the experimental model with regard to the gender of respondents. Results for the experimental and control group with regard to gender are shown in Table 3. In order to interpret the results of descriptive statistics more easily, they are presented according to the mean score for each group and for each level of measurement. The averages are calculated by adding together each student's scores on 18 claims and dividing that sum by 18 .

The total average scores are calculated from the average score obtained for each student. The statistically significant difference between the median in the final survey in comparison to the median in the initial survey was confirmed by the appropriate test (Wilcoxon Signed Ranks Test). The results are shown in Table 3. We should emphasise that the aforementioned test compares the median for the dependent samples and not the arithmetic mean of the samples. However, Table 3 shows the arithmetic means for the sake of comparison. The comparison was done in regards to the variable gender with two groups: male and female.

Table 3

Differences between the experimental and the control group in the initial and final measurement with regard to gender

\begin{tabular}{|c|c|c|c|c|c|c|c|}
\hline \multirow[b]{2}{*}{ Group } & \multirow[b]{2}{*}{ Variable } & \multirow[b]{2}{*}{ Modality } & \multirow{2}{*}{$\begin{array}{c}\text { No. } \\
\text { of the } \\
\text { students }\end{array}$} & \multicolumn{2}{|c|}{ Mean Score } & \multirow{2}{*}{$\begin{array}{l}\text { Results of } \\
\text { Wilcoxon } \\
\text { test }\end{array}$} & \multirow[b]{2}{*}{$\begin{array}{c}\text { Significance } \\
p\end{array}$} \\
\hline & & & & $\begin{array}{l}\text { Initial } \\
\text { survey }\end{array}$ & $\begin{array}{l}\text { Final } \\
\text { survey }\end{array}$ & & \\
\hline \multirow{2}{*}{$\begin{array}{l}\text { Experimental } \\
\text { group }\end{array}$} & \multirow[t]{2}{*}{ Gender } & male & 33 & 2.57 & 2.24 & -4.788 & 0.00 \\
\hline & & female & 33 & 2.37 & 2.19 & -2.285 & 0.02 \\
\hline \multirow{2}{*}{$\begin{array}{l}\text { Control } \\
\text { group }\end{array}$} & \multirow[t]{2}{*}{ Gender } & male & 35 & 3.04 & 3.07 & -1.362 & 0.17 \\
\hline & & female & 33 & 2.71 & 2.76 & -1.833 & 0.07 \\
\hline
\end{tabular}


The findings of the summarized results of the students from the experimental group show that there is a statistically significant difference in boredom reduction after the introduction of creative teaching in the teaching process. Boredom has been significantly reduced. It has been confirmed by final survey (from 2.47 to 2.21 with value $\mathrm{z}=-4.806$ and $\mathrm{p}<0.001$ ).

The established impact of the experimental model with regard to gender shows that there is a statistically significant difference for the subgroups of the students with regard to gender. Namely, the reduction in boredom is observed in a particular gender of student; it is evident for the male students because the value $z=-4.788$ is statistically significant between the initial and the final investigation $(\mathrm{p}<0.001)$ and for the female students $\mathrm{z}=-2.285$ with the value $\mathrm{p}=0.02$.

The analysis for the control group shown in Table 2 indicates that there is a statistically significant difference in the increase in boredom among the students of the control group. The difference was significantly increased in the final survey as well (an increase of the mean score from 2.88 to 2.92 with the value of Wilcoxon test 2.198 and $p=0.03$ ).

In the control group there was no statistically significant change in the reduction of boredom between initial and final measurement among male students $(\mathrm{p}=0.173)$ or female students $(\mathrm{p}=0.067)$.

The third research question investigated the influence of the experimental model in relation to the classical-traditional model in regards to the students' achievement.

The analysis of the results for the experimental group shows a change among students with different passing marks. It is presented in Table 4. A detailed analysis shows a statistically significant reduction in boredom among students with a passing mark 3 (good) with the value of $\mathrm{z}=-2.889 \mathrm{p}<0.01$; the passing mark 4 (very good) with the value of $\mathrm{z}=-2,151 \mathrm{p}<0,05$; and the passing mark 5 (excellent) with the value of $\mathrm{z}=-3,011 \mathrm{p}<0,051$. The level of boredom in the class was reduced among the students with the passing mark 2 (satisfactory), but this reduction was not statistically significant $(\mathrm{p}=0.06)$.

Table 4

Differences between experimental and control groups with regard to the students' passing marks

\begin{tabular}{lccccccc}
\hline \multicolumn{1}{c}{ Group } & Variable & Modality & $\begin{array}{c}\text { No. of the } \\
\text { students }\end{array}$ & \multicolumn{2}{c}{ Mean Score } & $\begin{array}{c}\text { Results of } \\
\text { Wilcoxon } \\
\text { test }\end{array}$ & $\begin{array}{c}\text { Significance } \\
\text { p }\end{array}$ \\
\hline $\begin{array}{l}\text { Experimental } \\
\text { group }\end{array}$ & Mark & 2 & 4 & 4.14 & 3.60 & 1.841 & 0.06 \\
& & 3 & 21 & 3.29 & 2.98 & -2.889 & 0.00 \\
& 4 & 23 & 2.22 & 2.03 & -2.151 & 0.03 \\
& & 5 & 18 & 1.46 & 1.25 & -3.011 & 0.00 \\
Control & Mark & 2 & 12 & 4.71 & 4.71 & 0.308 & 0.76 \\
group & & 3 & 29 & 3.23 & 3.29 & -2.257 & 0.02 \\
& & 4 & 15 & 2.08 & 2.09 & -0.522 & 0.60 \\
& & 5 & 12 & 1.22 & 1.26 & -1.065 & 0.29 \\
\hline
\end{tabular}


The analysis of the control group indicates that there was a statistically significant change among students who had the passing mark 3 (good) with the value of $z=-2.257$ $\mathrm{p}<0.01$, but this change implies the increase of boredom rather than reduction of boredom in class. The increase of boredom was observed among the students with the passing mark 2 (satisfactory), 4 (very good) and 5 (excellent), but it is not statistically significant due to the value of $\mathrm{p}>0.05$.

\section{Discussion}

At the beginning of the research, the students from the experimental and control groups were investigated. The results of the Mann-Whitney U test showed that there was no statistically significant difference between participants' responses to items, in other words, it was a uniform distribution. Thus, it was confirmed that we can use the experimental model.

Experimental treatment consisted of teaching units for the experimental group that was presented to students in a creative approach. The students in the control group were presented the content in a traditional way. The final measurement was performed after all the teaching units were completed. The results of the final measurement showed the impact of the experimental model because boredom was reduced according to all items in the questionnaire. It was observed that boredom was reduced among the students from the experimental group (in the final survey as opposed to the initial survey) for each item. In other words, the effect of creative teaching is evident, which obviously reduced the students' boredom.

In the final investigation of the students from the control group, there were also statistically significant changes in the boredom in the initial and final survey results. The changes were random in case of 17 items ( $p>0.05$ ), and only one item indicated a statistically significant change $(\mathrm{p}=0.004)$. The same is valid for the summary statistics results. However, this change in all items implies an increase rather than a reduction in boredom.

Therefore, the application of the classical approach increases the level of boredom among students. This result shows that the way of teaching directly affects the level of boredom among students. Besides, this finding gives clear guidance to all teachers emphasizing the most effective approach for teaching. So, if we want to make the teaching process interesting and challenging for students, we need to organise it creatively, and this creativity will remove boredom and increase its effectiveness.

Based on the above facts, it can be concluded that the first hypothesis is confirmed, therefore, creative teaching reduces students' level of boredom.

The above results are consistent with the results from other studies that indicate that a creative approach in teaching process can more effectively meet students' needs and perceive the characteristics of each child, especially gifted and talented children. Thus, this approach can be successfully designed and implemented for children from the $1^{\text {st }}$ to the $4^{\text {th }}$ grade. (Pejić et al., 2007,). 
George (2003) also points out that such enrichment in teaching expands and deepens the acquired experience, and provides experiences and activities which greatly reduce uniformity and monotony in teaching. One of the ways of explaining the obtained results would certainly be that the basic intention of the creative process (according to Bognar et al., 1994) is to gain experience that creates a sense of self-confidence, selfworth, and self-esteem, which is in line with Maslov's scale of basic needs that leads an individual to the very top - self-realization. Certainly, there would be little room for boredom in teaching while struggling to develop self-confidence.

The use and encouragement of creative potential and creative abilities, encouraging motivation for learning, increasing teaching activities, improving relationships among all participants in the teaching process, facilitating collaborative learning, encouraging innovation, increasing the sense of satisfaction and reducing fear, and increasing school achievement are some of the many positive aspects of creative teaching for both students and teachers (Zuliani et al., 2015). The results are in a line with the opinions of other authors and previous knowledge, where it is stated that creative work releases creative energy and encourages participation in the teaching process (Stevanović, 1986).

There are various methods for reducing boredom in the teaching process. Some of them are encouraging creativity through various approaches which trigger curiosity, perseverance, the power of observation, the formation of one's own thoughts, the development of initiative, independence, formation of personality, and encouraging motivation for learning, conducting more teaching activities, improving relationships among all participants in the teaching process, facilitating collaborative learning, encouraging innovation, increasing the sense of satisfaction and reducing fear, and increasing school achievement (Zuliani et al., 2015).

The obtained results are similar to the observations (Balazević, 2010) that indicate the importance of the method and strategy of a teacher's work. In order to encourage mental processes and creativity, the teacher's approach must be based on openness, flexibility, communication, encouragement, and evaluation of various and unusual opinions of other authors who emphasize that innovation increases students' activity and encourages their creativity.

The results of our research show that achievements influence students' emotional reactions in school, meanwhile, emotional reactions affect the strategies of confrontation, or dealing with different situations that a student can adopt and use (Macklem, 2008). Furthermore, it also affects learning strategies.

In addition, in order to investigate the difference between groups or within groups, we analysed the results with regard to gender and passing marks.

The second hypothesis of the research stated that the experimental model reduces the level of boredom among both male and female students. Research findings showed that there is a statistically significant reduction in boredom after the introduction of creative teaching approach among students from the experimental group, both male and female. 
The statistically significant difference was observed in reducing the boredom of the students from the experimental group upon the final survey in comparison to the initial survey for all students from the experimental group, regardless of gender. Namely, the reduction is evident not only for male students $(\mathrm{p}<0.001)$, but also for female students $(\mathrm{p}=0.022)$.

Statistically significant difference in the control group refers to the increase in boredom. So, the classic way, i.e. the traditional approach affects the increase of boredom for all students in the group, both male and female. Findings suggest that the creative teaching approach positively influences male and female students equally and reduces boredom among both female and male students. Findings confirmed the second hypothesis about the effect of the experimental model with regard to gender. Buckley and Saarni (according to Macklem, 2008) point out that due to the attitudes related to emotional judgments, we can predict school achievement of students. Thus, students with more negative emotions toward school tend to have lower achievement at school. The teaching process that encourages and enables creativity, for both students and teachers, has a particularly favourable influence on emotions in the teaching process (Bognar \& Kragulj, 2009).

According to the research of Kolak and Majcen (2011), the state of relaxation had the highest mean score among positive emotions of students, while the most prominent emotion was curiosity. For the negative emotions, students, both male and female, indicated boredom as the most intense emotion. The authors pointed out that intensity was equal for both positive and negative emotions with regard to gender. According to the mentioned authors, the gender variable did not significantly affect the emotional states of the students for the majority of presented emotions. It was also shown in this study in the control group.

However, significant changes occurred in the reduction of boredom when it comes to gender in the experimental group, and the possible reasons were that different individual potentials were recognised and encouraged during the creative teaching process. It is believed that positive emotions promote the use of flexible and creative learning strategies that are associated with the use of metacognitive strategies by elaboration, organization, and critical thinking. It certainly leads to better achievement. Likewise, positive student emotions (e.g., hope or enjoyment while learning) are associated with different motivational processes, such as greater effort, self-regulation, deeper cognitive processing, and less thoughts that are irrelevant to the task. Pleasant emotions such as curiosity, enthusiasm, and joy help the process of learning and make the process more successful. Higher-level cognitive functions are blocked while in the state of vulnerability (usually testing and testing situations), thus, students cannot think properly (Miljković \& Rijavec, 2009).

The research has determined the influence of the experimental model on the students with regard to their English language marks. The results show that reduced boredom in teaching process was evident among all students $(\mathrm{p}<0.05)$, except for those who had a 
passing mark of 2 (satisfactory). Even with these four students with satisfactory grades, the reduced boredom in the class was observed, but this change was not statistically significant $(p=0.066)$. The findings of the mean scores show that the students with the passing mark of 2 have emphasized the importance of the teaching approach due to the fact they showed the highest level of boredom. It would be important to examine whether the particular approach performed for the weak students affected their achievement. The evidence for this claim would help many teachers to solve the motivation and boredom issues of weaker students, and achieve better results.

The results of the control group confirmed that the traditional teaching approach increases boredom among students regardless of their marks or gender.

All of the above-mentioned statements support the confirmation of the third hypothesis which indicated the positive effect of the experimental model on students with regard to their marks in English.

Emotional reactions of students are strongly related to the learning process, i.e., its outcomes and results. Thus, the emotional reactions of curiosity, enthusiasm, and joy contribute to success, while, on the contrary, the negative emotional reactions of students contribute to failure. Positive emotions in teaching should certainly be used because they help teachers to successfully solve different teaching problems, activate thought processes of a higher order, and significantly influence creativity (Rijavec et al., 2008). Thus, successful teaching is considered to be a teaching process that will bring joy to students and meet their needs for personal growth and development (Bognar \& Kragulj, 2009).

\section{Conclusion}

Education is one of the key factors in every individual's life. A good society cannot exist without quality education. Striving for quality education requires interesting and effective teaching, which is a cornerstone of success.

Like adults, students are eager to do what they are interested in and what is interesting to them, which is also valid for the teaching process.

When it comes to successful teaching, it is inevitable to emphasize the importance of creativity in students.

Monotony and uniqueness lead to boredom in the teaching process, boredom stops and suppresses the student's will and desire for work, and stops the ability to work creatively.

The findings of the research have also shown that the creative model of teaching reduces boredom in the teaching process in general, regardless of gender and students' achievement. The higher level of creativity is, the less chance of boredom in the teaching process.

There are several limits to the study. One of them is that the study was conducted on lower grade students; it should also be conducted on middle-school students in order to see the effects of the experimental model. The study is also limited in the sense that 
the experimental model was not applied in other subjects, so that the results can only be tested in English language teaching.

\section{References:}

Andrilović, V., \& Čudina, M., (1988). Psihologija učenja i poučavanja. [Psychology of learning and teaching]. Zagreb: Školska knjiga

Balažević, E. (2010). Kreativnost u nastavi. Učitelji i organizacija kreativnih aktivnosti u nastavi glazbene kulture. [Creativity in Teaching]. Život i škola. 56(23). 181-184.

Bognar L., \& Bognar, B. (2007). Kreativnost učitelja kao značajna kompetencija nastavničke profesije. [Creativity of Teachers as a Significant Competence of a Teacher Profession]. In N. Nani! (Ed.), Zbornik radova "Kompetentnost i kompetencije učitelja". [Book of Proceedings, Competence and Competence of Teachers] (pp. 421-428). Osijek: Sveučilište Josipa Jurja Strossmayera, Učiteljski fakultet u Osijeku i Kherson (Ukraine): Kherson State University Kherson.

Bognar, L. (1991). Igre - zbirka odgojno-obrazovnih igara. [Games-Didactic games]. Osijek: Vlastito izdanje.

Bognar, L., \& Kragulj, S. (2009). Emocije u nastavi. [Emotions in the Teaching Processes] Beograd: Institut za pedagoška istraživanja.

Bognar, B., Uzelac, M., \& Bagić, A. (1994). Budimo prijatelji, priručnik odgoja za nenasilje $i$ suradnju. [Let's Be Friends:Manual for Nonviolence and Cooperation]. Zagreb: Biblioteka Slon.

Bowkett, S. (2007). Jumpstart. Creativity. London and New York: Routledge Taylor and Francis Group.

Cowley, S. (2006). Tajne uspješnog rada u razredu. [The Secrets of Successful Work in Classrooms]. Zagreb: Školska knjiga.

Čudina-Obradović, M. (1990). Nadarenost:razumijevanje, prepoznavanje, razvijanje. [Talent: Understanding, Identifying, Developing]. Zagreb: Školska knjiga.

Daschmann, E. C., Goetz, T., \& Stupnisky, R.H. (2011). Testing the predictors of boredom at school: Development and validation of the precursors to boredom scales. Britisch Journal of Educational Psychology, 81(3), 421-440. https://doi.org/10.1348/000709910X526038

Dubovicki, S.(2016). Kreativnost u sveučilišnoj nastavi. [Creativity in university education] Osijek: Sveučilište J.J.Strossmayer, Fakultet za odgojne i obrazovne znanosti.

George, D. (2004). Obrazovanje darovitih. [Gifted Education]. Zagreb: Educa.

Kolak, A., Majcen, M. (2011). Emocionalne reakcije učenika u nastavnom procesu kao poticaj razvoja kreativnosti, In A. Gojkov-Rajic, \& G. Grozdanka (Eds.), The gifted in the process of globalization, 337-360. http://www.uskolavrsac.edu.rs/Novi \%20sajt \% 202010/ Dokumenta/ Izdanja/16 \%20Okrugli \%20sto/Kolak, \%20Majcen \%20- \%2027.pdf

Macklem, G. L. (2008). Practitioner's guide to emotion regulation in school-aged children. New York: Springer-Press.

Milijević, S. (1984). Odsustvo pažnje u nastavnom procesu. Sarajevo: Zavod za udžbenike i nastavna sredstva. 
Milijević, S. (1989). Zbirka didaktičkih igara : priručnik za vaspitače u predškolskim organizacijama i nastavnike pripremnih odjeljenja. [Collection of Didactic Games: Manual for Educators in Preschool Organizations and Teachers of Preparatory Classes.]. Sarajevo: Svjetlost.

Miljković, D., \& Rijavec, M. (2009). Važnost pozitivnih emocija u odgoju i obrazovanju. [The Significance of Positive Emotions in Education]. Napredak, 150(3-4), 488-506.

Pejić, P., Tuhtan-Maras, T., \& Arrigoni, J. (2007). Suvremeni pristupi poticanju dječje darovitosti s kreativnim radionicama. [Contemporary Approaches to Encouraging Childcare with Creative Workshops]. Magistra Iadertina, 2(1), 133-149. https://doi.org/10.15291/magistra.885

Pekrun, R., Frenzel, A.C., Goetz, T., \& Perry,R. P. (2007). The control-value theory of achievement emotions: An integrative approach to emotions in education. In Emotion in education (pp. 13-36). Academic Press. https://doi.org/10.1016/B978-012372545-5/50003-4

Pekrun, R., Goetz, T., Daniels, L. M., Stupnisky, R. H., \& Perry, R. P. (2010). Boredom in achievement settings: Exploring control - value antecedents and performance outcomes of a neglected emotion. Journal of Educational Psychology, 102 (3), 531-549. https://doi. org/10.1037/a0019243

Perić, B. (2015). Kreativnost u nastavi. [Creativity in teaching]. Život i škola: časopis za teoriju i praksu odgoja i obrazovanja, 61(1), 145-150.

Rijavec, M., Miljković, D., \& Brdar, I. (2008), Pozitivna psihologija: znanstveno istraživanje ljudskih snaga i sreće. [Positive Psychology: The Scientific Research of Human Strengths and Happiness ]Zagreb: IEP.

Simel, S., Gazibara, S. (2013). Kreativnost u nastavi hrvatskoga jezika. [Creativity in Croatian Language Teaching] Život i škola: časopis za teoriju i praksu odgoja i obrazovanja, 59(29),188204.

Starko, A. J. (2010). Creativity in the Classroom. New York: Routledge. https://doi. org/10.4324/9780203871492

Sternberg, R. (2005). Kognitivna psihologija. [Cognitive Psychology] Jastrebarsko: Naklada Slap. Stevanović, M. (1986). Kretaivnost učenika i nastavnika. Pula: Istarska naklada

Vizek-Vidović, V, Vlahović-Štetić V., Rijavec M., \& Miljković D. (2003). Psihologija obrazovanja. [Educational Psychology] Zagreb: IEP

Zuliani, Đ., Matić, M., \& Keteleš, V. (2015). Poticanje kreativnosti u nastavi informatike. Život i škola : časopis za teoriju i praksu odgoja i obrazovanja. [Encouraging Creativity When Teaching Computer Science], 61(1) 25-35.

\author{
Marijana Radeljić \\ Elementary school "Stjepan Radić", Imotski \\ Ul. fra Stjepana Vrljića 13 \\ 21260 Imotski, Croatia \\ marijana.radeljic@gmail.com
}




\section{Hazim Selimović}

Faculty of Education

University of Travnik

Aleja konzola no. 5, 72270 Travnik, Bosnia and Herzegovina hazim.selimovic@mail.com

\section{Siniša Opić}

Department of Education

Faculty of Teacher Education,

University of Zagreb

Savska cesta 77, 10000 Zagreb, Croatia

sinisa.opic@ufzg.hr

\section{Nermin Mulaosmanović}

Faculty of Education

University of Travnik

Aleja konzola no. 5, 72270 Travnik, Bosnia and Herzegovina nerminmulaosmanovic81@gmail.com

\section{Zehrina Selimović}

Faculty of Education

University of Travnik

Aleja konzola no. 5, 72270 Travnik, Bosnia and Herzegovina zehrina.selimovic@gmail.com 


\section{Utjecaj kreativnoga pristupa na smanjenje dosade u nastavi}

\section{Sažetak}

Kreativnost, kao jedan od ključnih faktora uspješnosti, ponajprije bi trebala biti zastupljena u odgojno-obrazovnim ustanovama u svim segmentima života, počevši od predškolskih pa sve do visokoobrazovnih institucija. Polazeći od pretpostavke da je jednolična, monotona i nezanimljiva nastava jedna od glavnih prepreka uspješnoga obrazovanja učenika, cilj je ispitati kreativan pristup nastavi u svrhu smanjenja dosade u učionicama.

Uzorak se sastojao od 134 ispitanika rasporedenih u eksperimentalnu $(N=66)$ i kontrolnu $(N=68)$ skupinu. Nastava u eksperimentalnoj skupini provodila se primjenom kreativnoga pristupa nastavnika dok je u kontrolnoj skupini primijenjen tradicionalan pristup.

Istraživanje je provedeno pomoću istraživačkoga dizajna prije primjene eksperimentalnoga modela i poslije primjene. Cilj istraživanja bio je ispitati $i$ utvrditi utječe li uvođenje kreativnosti u nastavu na njezinu učinkovitost, a time $i$ na smanjenje dosade.

Analiza rezultata finalnoga mjerenja pokazala je da se kod učenika eksperimentalne skupine znatno smanjila razina dosade u odnosu na kontrolnu skupinu. Rezultati su pokazali da je primijenjeni kreativni model nastave djelovao pozitivno na smanjenje dosade.

Ključne riječi: kreativnost, kreativan nastavnik, učinkovita/ suvremena nastava, dosada.

\section{Uvod}

Obrazovanje je temelj svakog društva i bez kvalitetnoga obrazovanja nema ni uspješnoga društva. Da bi obrazovanje bilo uspješno, neophodno je inovirati nastavu kroz promjene koje će doprinositi uspješnom usvajanju nastavnoga sadržaja. Kada se govori o uspješnoj nastavi, neizbježno je govoriti o kreativnosti jer je kreativnost osnova uspješne nastave.

Danas većina autora naglašava da je kreativnost sposobnost stvaranja nečega što je novo, originalno i vrijedno, odnosno što izaziva iznenađenje, što nije stereotipno i što izlazi iz uobičajenih načina razmišljanja (Sternberg, 2005) Gallager (1986; prema Vizek, Vidović i sur., 2003) je definirao kreativnost kao mentalni proces kojim osoba stvara nove ideje ili produkte, ili kombinira postojeće ideje i produkte na inovativan način. 
Kreativnost je i jedna od kvaliteta ličnosti koja svakom pojedincu omogućuje realizaciju samog sebe do punog potencijala. Osim toga, kreativnost podrazumijeva upotrebu divergentnoga mišljenja, pronalaženje više odgovora na isto pitanje, oslobađanje emocija, humora te potiskivanje straha i dosade (Dubovicki, 2016)

Sa sigurnošću se može reći da je kreativnost ključ uspjeha u svim segmentima života, pa je tako i u obrazovanju uspješna nastava rezultat kreativnoga pristupa učenju. „Proučavanje kreativnosti danas je dominantno u službi odgoja i obrazovanja gdje se škola kao mjesto sustavnog razvijanja smatra jednom od osnovnih predispozicija za razvoj kreativnosti iz kreativnog potencijala pojedinca" (Simel, Gazibara, 2013, str. 189).

Današnji način života zahtijeva nezavisnoga, odgovornoga i kreativnoga pojedinca te se od obrazovanja traži razvijanje kreativnoga i kritičnoga razmišljanja kod učenika. Učenici kreativnost povezuju uz nešto pozitivno, zanimljivo i zabavno, a uglavnom uz predmete koji podrazumijevaju izradu praktičnih radova. Učenici, također, smatraju da bi se kreativnosti u školi trebalo dati više prostora i to ne samo u predmetima koji su vezani uz praktični rad nego i u ostalim predmetima (Perić, 2015)

Kroz kreativnost učenici stvaraju nove ideje, organiziraju informacije, razmišljaju o konceptu pitanja. Osnovna je svrha kreativnosti da dijete razumije svijet oko sebe i da se ne boji ideja (Bowkett, 2007) Upravo kreativnost stvara nove ideje, a ideje mijenjaju svijet. „Bez kreativnosti nema inovacija, a svijetu je potrebna mlada generacija s novim idejama, generacija koja može mijenjati i unaprjeđivati postojeće ideje" (Simel, Gazibara, 2013, str. 190).

Kako bi se kreativnost mogla razvijati potrebno je imati kreativnoga nastavnika koji će tu kreativnost razvijati kod učenika. Kreativnost učitelja pretpostavka je razvoja kreativnosti učenika i osobina koja se može steći i graditi (Bognar, L., Bognar, B., 2007) Zuliani, Matić, Keteleš (2015) naglašavaju da uspjeh u učeničkoj kreativnosti ovisi o njihovim predispozicijama i osobnim afinitetom napredovanja, ali i o učiteljevoj sposobnosti u području kreativnosti i stvaralaštva, pri čemu se osobito misli na pripremljenost te organizaciju i oblikovanje nastavnoga procesa.

Nastavnik kod učenika može razvijati stav i vještine kreativnosti, poučiti učenike kreativnim metodama u svojem predmetu i razvijati razred otvoren za kreativno rješavanje problema (Starko, 2010)

Nastavnik ima neograničen raspon kreativnosti u svojemu reagiranju prema učenicima. Kreativnost je ozbiljna učenička aktivnost, ali to ne znači da ne može biti povezana s humorom. Tako Čudina-Obradović (1990), preporučuje više igara koje su poticajne za razvoj kreativnosti, a također Bognar (1991) i Milijević (1989) preporučuju igre za nastavu u kojima su vješto spojeni humor i kreativne aktivnosti učenika.

Nedostatak kreativnosti dovodi do pojave dosade ili monotonije, što je čest slučaj u školama. „Dosada je stanje neugodnih osjećaja, pomanjkanja poticaja i niskih fizioloških podražaja" (Pekrun, Goetz, Daniels, Stupnisky, Perry, 2010, str. 532). Ako je učeniku nastava dosadna, ne može se očekivati njegov uspjeh. Sindrom dosade je, 
pored svakodnevnoga pritiska za postizanjem uspjeha u školi, sigurno najveći problem učenika, kao i značajan uzrok pojave smetnji u nastavi.

Andrilović i Čudina (1988) naglašavaju da je dosada stanje (organizma) izazvano vanjskim podražajima koji su pretjerano rijetki ili pretjerano jednolični i čije duže trajanje izaziva traženje zanimljivijega izvora podražaja.

Dosada, može biti ozbiljna motivacijska blokada koja interferira s učenjem (Pekrun i sur., 2002) Svima nam je poznato da učenici često osjećaju dosadu na nastavi. Prema Pekrunu (2007) do dosade dolazi onda kada učenici smatraju da je gradivo nevažno i/ili kada percipiraju da imaju preveliku ili premalu kontrolu nad situacijom.

Daschmann i sur. (2011) kao glavni uzrok dosade u nastavi navode monotoniju u razredu, tj. procjenu učenika da je nastavni predmet nevažan, kao i nedostatak ciljeva.

Ako je učeniku nastava dosadna, a posebno ako izostaje podrška nastavnika, može se očekivati da će se pojaviti odbojnost pri usvajanju nastavnoga gradiva, a samim time i neuspjeh u nastavi.

Prema Kolak, Majcen (2011) zabrinjavajuće je visok intenzitet dosade.

Učitelji i nastavnici u današnjim školama trebali bi osigurati ozračje koje će učenike poticati na kreativan rad i to razgovorom, zajedničkim planiranjem s učenicima, postavljanjem neobičnih pitanja ili ideja, prihvaćanjem učeničke inicijative (Cowley, 2006)

Upravo je takva škola bila motiv ovoga istraživanja. Postavljeni cilj je utvrđivanje utjecaja kreativnoga pristupa u nastavi kao eksperimentalnoga modela (koji se provodio u eksperimentalnoj skupini) na smanjenje dosade u nastavi u odnosu na tradicionalni oblik nastave koji se provodio u kontrolnoj skupini.

Sukladno cilju istraživanja postavljene su sljedeće hipoteze:

Kreativna nastava imat će pozitivan utjecaj na smanjenje dosade u nastavi. Očekuje se da će ispitanici u eksperimentalnoj skupini iskazivati nižu razinu dosade u nastavi $\mathrm{u}$ odnosu na ispitanike u kontrolnoj grupi.

Očekuje se da će kreativna nastava smanjiti razinu dosade i kod dječaka i kod djevojčica.

Očekuje se da će kreativna nastava smanjiti razinu dosade kod svih učenika bez obzira na ocjenu iz Engleskoga jezika.

\section{Metode}

\section{Postupak}

Istraživanje o utjecaju kreativne nastave na smanjenje dosade u nastavi kod učenika provedeno je u školskoj godini 2016./2017. Za provođenje istraživanja dobivena je suglasnost ravnatelja osnovnih škola u kojima je provedeno istraživanje. Prije samog istraživanja ispitanici su upoznati s njegovim značenjem i načinom njegova provođenja. Također, ispitanicima je objašnjeno da je istraživanje isključivo u znanstvene svrhe. Na početku istraživanja, a prije uvođenja eksperimentalnoga modela u eksperimentalnu 
skupinu, grupe su ujednačene na osnovi rezultata inicijalnoga mjerenja u skupinama. Ujednačavanje grupa rađeno je na osnovi razine dosade. Svi su učenici popunili anketni upitnik na početku školske godine: i oni iz eksperimentalne, i oni iz kontrolne skupine. Nakon toga su učenici eksperimentalne skupine podvrgnuti eksperimentalnom tretmanu koji se sastojao od toga da se nastava Engleskoga jezika izvodila po posebnoj metodologiji koju je karakterizirao kreativni pristup.

Eksperiment se provodio tako da se nastava Engleskoga jezika odvijala uz mnoštvo verbalnih i vizualnih poticaja, priča i razgovora s učenicima te primjenom slikovnih kartica (flash cards). Primijenjene su i različite didaktičke igre koje su se prilagođavale edukativnom i nastavnom sadržaju. Na samom početku učenicima su definirana pravila. Kao sredstvo u izvedbi nastave koristile su se omiljene igračke učenika koje su donosili od kuće. Sve ono što dijete ne može ili se iz bilo kojeg razloga ne usuđuje, odrađivalo se uz pomoć igračke tako da igračka ponavlja, odgovara na pitanja, pleše, pjeva. Na taj način učenici su se usmjeravali na izražavanje kroz scenski i lutkarski izraz. U nastavi se također primjenjivao rad u paru i skupinama, što je doprinosilo poticanju aktivnosti te stvaranju interaktivnoga i suradničkoga odnosa.

Jedna od novijih nastavnih metoda učenja jezika koja se primjenjivala je TOTAL PHYSICAL RESPONSE (TPR) koja je utemeljena na koordinaciji jezika i fizičkoga pokreta. U kontrolnoj skupini učenicima je reproduciran nastavni sadržaj primjenom tradicionalnoga frontalnog oblika rada. Eksperiment se provodio tijekom 2016./2017. školske godine, a na samom kraju je $s$ učenicima ponovo provedeno anketno ispitivanje.

\section{Uzorak}

Istraživanje je provedeno među učenicima $(\mathrm{N}=134)$ četvrtih razreda Osnovne škole Stjepan Radić u Imotskom tijekom 2016./2017. školske godine. Od ukupnoga broja učenika $(\mathrm{N}=134)$ u istraživanju je sudjelovalo 66 djevojčica i 68 dječaka.

Hi-kvadrat testom željeli smo ispitati ujednačenost uzorka s obzirom na spol i ocjenu iz Engleskoga jezika.

Vrijednost $\chi^{2}=0,030$ uz razinu značajnosti 0,863 pokazuje da je uzorak ujednačen po spolu jer nema statistički značajne razlike između dječaka i djevojčica. Eksperimentalna grupa ima 66 (49,3\%) učenika od toga $33(50 \%)$ dječaka 33 (50\%) djevojčica. Kontrolna grupa ima 68 (50,7 \%) učenika, od toga $35(51,5 \%)$ dječaka i 33 (48,5\%) djevojčica.

Uzorak ispitanika po uspjehu pokazuje da u eksperimentalnoj skupini imamo 4 $(6,1 \%)$ dovoljnih učenika, 21 (31,8 \%) učenika s dobrim uspjehom, $23(34,8 \%)$ s vrlo dobrim uspjehom i 18 (27,3\%) učenika s odličnim uspjehom.

Kontrolna skupina ima 12 (17,6\%) dovoljnih učenika, 29 (42,6\%) dobrih učenika, $15(22,1 \%)$ vrlo dobrih učenika i $12(17,6 \%)$ odličnih učenika.

Vrijednost $\left(\chi^{2}=1,200 ; p=0,273\right)$ za učenike s odličnim uspjehom, $\left(\chi^{2}=1,684\right.$; $\mathrm{p}=0.194)$ za učenike vrlo dobrim uspjehom, $\left(\chi^{2}=1,280 ; \mathrm{p}=0,258\right)$ za učenike $\mathrm{s}$ dobrim uspjehom i $\left(\chi^{2}=3,267 ; \mathrm{p}=0,07\right)$ za učenike $s$ dovoljnim uspjehom pokazuje da je uzorak ujednačen po uspjehu između eksperimentalne i kontrolne skupine jer 
nema statistički značajne razlike između učenika kada je u pitanju njihov uspjeh u prethodnoj školskoj godini.

\section{Instrumenti}

U istraživanju je primijenjen ISC-S Inventar „Procjena dosade u nastavi” (Milijević, 1984, str. 13). Skala se sastoji od peterostupanjske ljestvice Likertova tipa koja sadrži 18 tvrdnji, na kojoj su učenici izražavali svoj stupanj slaganja s navedenim tvrdnjama od 1 - nikad do 5 - uvijek. Prvi dio upitnika namijenjen je prikupljanju osnovnih sociodemografskih podataka o učenicima koji su uključeni u istraživanje, a odnose se na spol, razred, školu i školski uspjeh. Zatim slijedi kratko obrazloženje svrhe instrumenta, sadržaj problema koji se istražuje i način odgovaranja na postavljene tvrdnje.

Sva su pitanja u instrumentu negativno formulirana, npr. Nastava je uglavnom dosadna ili Učenje mi nije zanimljivo. Stoga odgovori s nižim vrijednostima (1 i 2) znače bolje stanje, dok odgovori s višim vrijednostima (4 i 5) znače lošije stanje odnosno veću dosadu.

Anketiranje je provedeno na početku školske godine kako bi se dobio uvid u inicijalno stanje, a finalno stanje ispitano je na kraju školske godine.

Anketa je bila anonimna, a po završenom finalnom anketiranju upitnici su upareni za svakog učenika (inicijalni s finalnim) kako bi se analizom mogle utvrditi promjene u odgovorima.

Pouzdanost upitnika testirana je metodom interne konzistentnosti prema Alpha modelu (Reliability Analysis). Cjelokupna skala s 18 čestica pokazuje vrijednost Cronbach alpha 0,983 u inicijalnom anketiranju i 0,984 u finalnom anketiranju.

\section{Rezultati istraživanja}

U cilju ispitivanja efikasnosti eksperimentalnoga modela potrebno je ispitati ujednačenost eksperimentalne i kontrolne skupine na inicijalnom mjerenju. Rezultati Mann-Whitneyeva $U$ testa od $(U=1821,000 ; z=-1,884 ; p=0,060)$ upućuju na zaključak da se skupine statistički značajno ne razlikuju, tj. da su ujednačene.

Kako bi se mogla napraviti prva analiza rezultata dobivenih na 18 tvrdnji od učenika eksperimentalne i kontrolne skupine kod inicijalnoga anketiranja u odnosu na istih 18, utvrđeno jesu li distribucije odgovora na pojedine tvrdnje slične normalnoj distribuciji. Provjera je napravljena pomoću Kolmogorov-Smirnovljeva testa. Dobivena vrijednost $\mathrm{p}=0,043$ pokazuje da nijedna od distribucija nije slična normalnoj distribuciji što znači da $\mathrm{u}$ analizi tih distribucija (tvrdnji) nije dozvoljeno koristiti parametrijske testove (t-testove za zavisne uzorke) već samo neparametrijske testove (Wilcoxon Signed Ranks Test).

Kako bi se Upitnik dosada u nastavi sa svojih 18 tvrdnji reducirao primijenjena je faktorska analiza. Ona je učinjena dva puta: jednom za odgovore kod inicijalnoga anketiranja učenika, drugi put za odgovore kod finalnoga anketiranja učenika. Prethodno su provedeni testovi kojima su provjereni uvjeti za provedbu faktorske analize. Kaiser- 
Meyer-Olkinova mjera adekvatnosti uzorka kod inicijalnoga anketiranja iznosi 0,971 i kod finalnog anketiranja 0,979.

Bartlettov test sfericiteta dao je sljedeće rezultate:

kod inicijalnoga anketiranja $\chi^{2}=3014,417 ; \mathrm{df}=153 ; \mathrm{p}<0,001$

kod finalnoga anketiranja $\chi^{2}=3172,946 ; \mathrm{df}=153 ; \mathrm{p}<0,001$

Prema tim rezultatima zaključuje se da postoje preduvjeti za provedbu faktorske analize. Faktorska analiza provedena je tako što je izračunata matrica interkorelacija za 18 tvrdnji (pitanja, varijabli) iz upitnika, izvršena je ekstrakcija faktora metodom glavnih komponenti, varimax rotacija faktora i izračunati su faktorski bodovi za sve ispitanike eksperimentalne skupine (66 učenika).

Prema Kaiser-Guttmanovom kriteriju određivanja značajnosti faktora prvi i jedini ekstrahirani faktor je značajan, odnosno struktura je jednofaktorska. Jedini faktor u strukturi objašnjava 77,5 \% ukupne analizirane varijance kod inicijalnoga anketiranja odnosno $79,1 \%$ kod finalnoga anketiranja.

U tablici 1 prikazana je nerotirana matrica faktorske strukture (za obje faktorske analize) budući da je u oba slučaja izdvojena samo jedna komponenta pa se rješenje ne može rotirati.

Tablica 1.

Kako bi se potvrdio utjecaj eksperimentalnoga modela na smanjenje dosade u nastavi, napravljena je usporedba rezultata između inicijalnoga i finalnoga mjerenja u obje skupine. Kako bi se bolje uočila razlika u prihvaćanju pojedinih tvrdnji od strane učenika eksperimentalne i kontrolne skupine, izračunate su po pojedinim tvrdnjama aritmetičke sredine te standardne devijacije. Rezultati testa prikazani su u tablici 2.

U eksperimentalnoj skupini kod inicijalnoga anketiranja, tablica 2, svi su prosjeci između 2,08 i 2,74. Ekstremno niski prosjek ima tvrdnja 1 (Kolutajući očima jedva čekam kraj sata) što znači da je ona najmanje zastupljena, dok najviši prosjek ima tvrdnja 13 (Uči mi se, a ne da mi se) koja je najviše zastupljena.

Kod finalnoga anketiranja eksperimentalne skupine, tablica 2, dobiveni su prosjeci između 1,86 i 2,44 , a to je niže nego kod inicijalnoga anketiranja. Niže vrijednosti znače da se razina dosade smanjuje. Uočena je pravilnost da se to smanjenje dosade primjećuje u prosjecima kod svake tvrdnje (2,08 > 1,86 kod prve tvrdnje, 2,26 > 2,05 kod druge tvrdnje itd.). Drugim riječima, uočava se učinak kreativne nastave koji je, očigledno, stvorio veću zainteresiranost (motiviranost) kod učenika i smanjio dosadu u nastavi.

Disperzija odgovora učenika eksperimentalne skupine i kod inicijalnoga i kod finalnoga anketiranja je osrednja. Vrijednosti standardnih devijacija kod većine varijabli inicijalnoga i finalnoga anketiranja ukazuju da nije riječ o homogenim obilježjima. Iz tablice 2 također se može uočiti nešto veća disperzija odgovora kod finalnoga anketiranja u odnosu na inicijalno anketiranje. 
U tablici 2 navedeni su rezultati neparametrijskoga Wilcoxonova testa uparenih vrijednosti za eksperimentalnu i kontrolnu skupinu. Rezultati pokazuju da je kod finalnoga anketiranja došlo do statistički značajne promjene u odgovorima učenika eksperimentalne skupine u odnosu na odgovore istih učenika kod inicijalnoga anketiranja. Statistički značajno smanjenje dosade evidentno je kod većine tvrdnji, kod njih 15 od ukupno 18 tvrdnji. Smanjenje dosade u nastavi zabilježeno je i kod tvrdnji 6, 7 i 8 , samo što to smanjenje nije statistički značajno.

U tablici 2 analiza odgovora napravljena je za učenike kontrolne skupine. Budući da je u toj skupini nastava Engleskoga jezika održavana primjenom frontalnoga oblika nastave, ne očekuju se neke bitne promjene kod finalnoga anketiranja u odnosu na inicijalno anketiranje.

Tablica 2.

Kod inicijalnoga anketiranja učenika kontrolne skupine (tablica 2) najniži prosjek od 2,16 dobila je tvrdnja 1 (Kolutajući očima jedva čekam kraj sata) dok je najviši prosjek od 3,13 dobila tvrdnja 6 (Ako mi je na satu dosadno, ne uključujem se, ne dižem ruku niti se aktiviram na neki drugi način). Kod finalnoga anketiranja učenika kontrolne skupine najniži prosjek od 2,37 je dobila ista tvrdnja 1 kao i kod inicijalnoga anketiranja, a najviši prosjek kod finalnoga anketiranja ima tvrdnja 6 kako je to bilo i kod inicijalnoga anketiranja. Viši prosjek kod finalnoga anketiranja ima i tvrdnja $8 \mathrm{~s}$ prosjekom od 3,15 (Nastavnik koji učenicima naređuje što će raditi, u pravilu je dosadan). Koeficijenti varijacije kreću se između 39 \% i 53 (ks) \% odnosno između 36 \% i 51 (es) \% što indicira nehomogena obilježja promatranih varijabli.

Rezultati za kontrolnu grupu pokazuju da je kod finalnoga anketiranja došlo do statistički značajne promjene u odgovorima učenika kontrolne skupine u odnosu na odgovore istih učenika kod inicijalnoga anketiranja. Promjene su kod 17 tvrdnji slučajne $(\mathrm{p}>0,05)$. Samo je kod tvrdnje 1 i sumarnog rezultata za sve tvrdnje promjena statistički značajna $(\mathrm{p}>0,05)$. Takav se rezultat očekivao budući da tijekom školske godine nije $\mathrm{u}$ kontrolnoj grupi mijenjan način izvođenja nastave pa se nije ni bitno promijenila zainteresiranost učenika, odnosno njihova zainteresiranost u tradicionalnoj nastavi je opala, a povećala se razina dosade.

Istraživanjem je utvrđivan i utjecaj eksperimentalnoga modela na spol ispitanika. Rezultati za eksperimentalnu i kontrolnu grupu za spol ispitanika prikazani su u tablici 3. Kako bi se rezultati deskriptivne statistike lakše tumačili prikazani su u obliku prosjeka za svaku skupinu i za svaki nivo mjerenja. Prosjeci su izračunati zbrajanjem odgovora svakog učenika na 18 tvrdnji i dijeljenjem tog zbroja s 18. Iz prosjeka dobivenog za svakog učenika izračunati su opći prosjeci. Statistička značajnost razlika između medijana kod finalnoga anketiranja u odnosu na medijan kod inicijalnoga anketiranja provjeravana je odgovarajućim testom (Wilcoxon Signed Ranks Test). Rezultati su iskazani u tablici 3. Treba naglasiti da navedeni test za zavisne uzorke uspoređuju medijane, a ne aritmetičke sredine uzoraka, no u tablici 3 iskazane su 
aritmetičke sredine radi usporedbe. Varijabla po kojoj je napravljena usporedba je spol s dvije vrijednosti: muški i ženski.

\section{Tablica 3.}

Dobiveni rezultati pokazuju da kod učenika eksperimentalne skupine postoji statistički značajna razlika u smanjenju dosade na nastavi nakon uvođenja kreativne nastave. Dosada je statistički značajno smanjena kako je utvrđeno ponovnim anketiranjem (pad prosjeka s 2,47 na 2,21 uz vrijednost $\mathrm{z}=-4,806$ i $\mathrm{p}<0,001$.

Utvrđena značajna razlika nije karakteristična samo za sve učenike eksperimentalne skupine nego i za podskupine učenika s obzirom na spol. Naime, kada se smanjenje dosade promatra kod pojedinoga spola učenika tada se može reći da ona postoji i kod dječaka jer je vrijednost $\mathrm{z}=-4,788$ statistički značajna između inicijalnoga i finalnoga stanja $(\mathrm{p}<0,001)$ i kod djevojčica $\mathrm{z}=-2,285$ uz vrijednost $\mathrm{p}=0,02$.

Analiza za kontrolnu skupinu učenika tablica 3 pokazuje da kod učenika kontrolne skupine postoji statistički značajna razlika u povećanju dosade. Ta je razlika statistički značajno povećana kako je utvrđeno ponovnim anketiranjem (porast prosjeka s 2,88 na 2,92 uz vrijednost Wilcoxonova testa 2, 198 i $\mathrm{p}=0,03$.).

Međutim, utvrđen značajan porast dosade nije karakterističan i za podskupine učenika kontrolne skupine s obzirom na spol. Naime, kada se taj porast dosade promatra kod pojedinoga spola učenika tada se može reći da on nije statistički značajan ni kod dječaka $(p=0,173)$ ni kod djevojčica $(p=0,067)$.

Treći zadatak je ispitivanje efikasnosti utjecaja eksperimentalnoga modela u odnosu na klasični model s obzirom na uspjeh (ocjenu) učenika u prethodnoj školskoj godini.

Analizom rezultata za eksperimentalnu skupinu uočavaju se promjene kod učenika s različitim ocjenama (tablica 4). Vrijednost $\mathrm{z}=-4,806 \mathrm{i} \mathrm{p}<0,01$ govori da je ta promjena statistički značajna. Detaljnom analizom uočava se statistički značajno smanjenje dosade kod učenika koji imaju ocjenu dobar $\mathrm{z}=-2,889 \mathrm{p}<0,01$; ocjenu vrlo dobar $\mathrm{z}=-2,151, \mathrm{p}<0,05$ i ocjenu odličan $\mathrm{z}=-3,011, \mathrm{p}<0,051$. Kod učenika koji su imali ocjenu dovoljan, smanjena je razina dosade na nastavi, ali to smanjenje nije statistički značajno $(\mathrm{p}=0,06)$.

Tablica 4.

Kada se analizira kontrolna skupina tada se vidi da je prosjek koji se odnosi na dosadu na nastavi porastao s 2,88 na 2,92. Taj je prosjek statistički značajan kod svih učenika ( $\mathrm{p}<0,05)$, ali i pojedinačno kod učenika koji su imali ocjenu dobar $\mathrm{p}<0,05$. Kod učenika s ocjenom dovoljan, vrlo dobar i odličan zabilježen je porast dosade, ali on nije statistički značajan jer je vrijednost $\mathrm{p}>0,05$.

\section{Diskusija}

$\mathrm{Na}$ početku istraživanja ispitani su učenici eksperimentalne i kontrolne skupine. Rezultati Mann-Whitneyeva U testa pokazali su da nema statistički značajne razlike 
u tvrdnjama ispitanika, dakle skupine su ujednačene čime je stvorena pretpostavka za primjenu eksperimentalnoga modela. Eksperimentalni tretman činile su nastavne jedinice za eksperimentalnu grupu koje su obrađivane na kreativan način. Učenici u kontrolnoj skupini sadržaje su obrađivali na klasičan način. Nakon odrađenih svih nastavnih jedinica napravljeno je finalno mjerenje. Rezultati finalnoga mjerenja pokazali su učinak eksperimentalnoga modela jer se dosada kod svih ispitivanih tvrdnji smanjila. Uočeno je da se kod učenika eksperimentalne skupine dosada smanjuje (kod finalnoga anketiranja u odnosu na inicijalno anketiranje) kod svake tvrdnje, ali kod ukupnog rezultata za sve tvrdnje skupa. Drugim riječima, uočava se učinak kreativne nastave koja je, očigledno, smanjila dosadu kod učenika.

Kod finalnoga anketiranja učenika kontrolne skupine također je došlo do statistički značajne promjene u dosadi na nastavi učenika kod inicijalnoga i finalnoga anketiranja. Promjene su kod 17 tvrdnji slučajne ( $p>0,05)$, samo je kod jedne tvrdnje promjena statistički značajna ( $p=0,004)$, ali i kod ukupnih rezultata. Međutim ta se promjena kod svih tvrdnji odnosi na povećanje, a ne smanjenje dosade. Dakle, što se više primjenjuje, klasičan način nastave povećava razinu dosade kod učenika. Upravo ovaj rezultat dodatno pokazuje da način izvođenja nastave utječe na razinu dosade kod učenika. Rezultati daju jasne smjernice svim nastavnicima o pravcu u kojem trebaju izvoditi nastavu. Dakle, ako želimo nastavu učiniti zanimljivom za učenike, moramo je organizirati na kreativan način, a upravo ta kreativnost će ukloniti dosadu i povećati efikasnost učenja.

Temeljem navedenih činjenica prva se hipoteza potvrđuje, odnosno, kreativna nastava smanjuje razinu dosade kod učenika.

Navedeni su rezultati u skladu i s drugim ispitivanjima koja ukazuju da kreativan pristup u nastavi može na kvalitetniji i neposredniji način uočiti i zadovoljiti osobitosti svakog djeteta, a posebno darovite djece, da se ovakav oblik rada može uspješno osmišljavati i provoditi u razrednim odjelima od 1. do 4. razreda za svu djecu (Pejić, Tuhtan-Maras, Arrigoni, 2007). Također Georgeu (2003) ističe da ovakvo obogaćivanje nastave proširuje i produbljuje stečeno iskustvo, osigurava iskustva i aktivnosti što uvelike smanjuje jednoličnost i monotoniju u nastavi. Jedan od načina objašnjenja dobivenih rezultata svakako bi mogao biti i taj što je osnovna namjera kreativnoga procesa (prema Bognar, Uzelac, Bagić, 1994) stjecanje iskustva koje stvara osjećaj samopouzdanja, vlastite vrijednosti i samopoštovanja, a što je u skladu s Maslovljevom ljestvicom osnovnih potreba koja vodi do samog vrha - samoostvarenja. Svakako da bi u tom smjeru razvoja samopouzdanja bilo malo prostora za dosadu na nastavi.

Korištenje i poticanje stvaralačkoga potencijala i kreativnih sposobnosti, poticanje motivacije za učenje, povećanje aktivnosti u nastavi, poboljšanje odnosa između svih sudionika u nastavi, omogućavanje suradničkoga učenja, poticanje inovativnosti, povećanje osjećaja zadovoljstva i smanjenje straha, povećanje školskoga uspjeha neki su od mnogobrojnih pozitivnih aspekata kreativne nastave i za učenike i za učitelje (Zuliani, Matić, Keteleš, 2015). Rezultati su u suglasnosti i s mišljenjima drugih autora s obzirom na dosadašnje spoznaje, kreativan rad oslobađa stvaralačku energiju i 
potiče sudjelovanje u nastavi (Stevanović, 1986). Razlozi smanjenju dosade u nastavi poticanjem kreativnosti kroz različite načine koji idu u prilog i ovim rezultatima su mnogobrojni, a neki od njih su svakako da se potiče radoznalost, upornost, moć zapažanja, formiranje vlastitih misli, razvijanje inicijative, samostalnosti te formiranje čovjeka i njegova duha, poticanje motivacije za učenje, povećanje aktivnosti u nastavi, poboljšanje odnosa između svih sudionika u nastavi, omogućivanje suradničkoga učenja, poticanje inovativnosti, povećanje osjećaja zadovoljstva i smanjenje straha, povećanje školskoga uspjeha (Zuliani, Matić, Keteleš, 2015).

Dobiveni rezultati u skladu su i sa zapažanjima (Balažević, 2010) koji upućuju na važnost metoda i strategija učiteljeva rada koje se, kako bi poticale mentalne procese i kreativnost, moraju temeljiti na otvorenosti, fleksibilnosti, komunikaciji, poticanju i vrednovanju različitih i neobičnih mišljenja. Također, dobiveni rezultati u skladu su s razmišljanjima drugih autora koji naglašavaju da inovacija povećava učeničku aktivnost i potiče njihovu kreativnost.

Rezultati istraživanja pokazuju da postignuća utječu na učenikovu emocionalnu reakciju u školi, dok emocionalna reakcija utječe na strategije suočavanja, odnosno nošenja s različitim situacijama koje učenik može usvojiti i koristiti (Macklem, 2008), ali i na strategije učenja.

Također su analizirani rezultati unutar skupina s obzirom na spol i školsku ocjenu kako bi se utvrdilo postojanje statističkih značajnih razlika između skupina, ali i unutar skupina.

Druga hipoteza istraživanja je očekivanje da eksperimentalni model smanjuje razinu dosade kod učenika i muškoga i ženskoga spola. Rezultati istraživanja pokazuju da kod učenika oba spola u eksperimentalnoj skupini postoji statistički značajno smanjenje dosade nakon uvođenja kreativne nastave.

Utvrđena statistički značajna razlika u smanjenju dosade učenika eksperimentalne skupine kod finalnoga anketiranja u odnosu na inicijalno anketiranje vrijedi ne samo za sve učenike te skupine, nego i za podskupine učenika s obzirom na spol. Naime, kada se to smanjenje promatra kod pojedinoga spola učenika, tada se može reći da ona postoji ne samo kod dječaka $(p<0,001)$, nego i kod djevojčica $(p=0,022)$.

Statistički značajna razlika u kontrolnoj skupini odnosi se na povećanje dosade kod ukupnoga rezultata. Dakle, klasični način poučavanja utječe na povećanje dosade s vremenom provedenim u ovakvom načinu rada i on je prisutan kod oba spola. Nalaz upućuje na zaključak da kreativna nastava podjednako pozitivno utječe na učenike i muškoga i ženskoga spola te da kod jednih i drugih smanjuje dosadu u nastavi. Rezultatima je potvrđena hipoteza o učinku eksperimentalnoga modela na spol učenika.

Buckley i Saarni (prema Macklem, 2008) ističu da se preko stavova povezanih s emocionalnim prosudbama može predvidjeti školski uspjeh, pa tako učenici s više negativnih emocija prema školi imaju i niži školski uspjeh. Nastavni proces koji potiče i omogućava kreativnost, kako učenika tako i nastavnika, ima posebno povoljan utjecaj na emocije u nastavi (Bognar i Kragulj, 2009). 
Prema istraživanju Kolak, Majcen (2011) među pozitivnim emocijama kod učenika se kao najviša izdvaja opuštenost, dok je kod učenica najistaknutija emocija radoznalosti. Među negativnim emocijama pak, učenici i muškoga i ženskoga spola najvećim intenzitetom doživljavaju emociju dosade. Ovi autori ukazuju da, kada je u pitanju spol, kod istovjetnih i pozitivnih i negativnih emocija intenzitet podjednak. Kategorija spola nije značajno utjecala na emocionalna stanja učenika u većini ponuđenih emocija prema navedenim autorima, što je pokazano i u ovome istraživanju u kontrolnoj grupi. Međutim do značajnih je promjena došlo u smanjenju dosade kada je u pitanju spol u eksperimentalnoj grupi, a mogući su razlozi da su do izražaja došli različiti individualni potencijali kreativnim pristupom u nastavi. Smatra se da pozitivne emocije pospješuju korištenje fleksibilnih i kreativnih strategija učenja te su povezane s korištenjem metakognitivnih strategija, elaboracijom, organizacijom i kritičkim mišljenjem, a to može voditi boljem uspjehu. Isto tako, pozitivne učeničke emocije (npr. nada ili uživanje u učenju) povezane su s različitim motivacijskim procesima poput većega ulaganja truda, samoregulacije, dubljega kognitivnog procesiranja i rjeđega pojavljivanja misli irelevantnih za zadatak. Ugodne emocije kao što su radoznalost, oduševljenje i radost pomažu proces učenja i čine taj proces uspješnijim, dok se u stanju ugroženosti (obično situacije ispitivanja i testiranja) blokiraju kognitivne funkcije višega reda, odnosno učenici lošije misle (Miljković i Rijavec, 2009).

Istraživanjem je utvrđivan utjecaj eksperimentalnoga modela na učenike s obzirom na ocjenu iz Engleskog jezika. Rezultati pokazuju da je smanjene dosade u nastavi nastalo kod svih učenika i ono je statistički značajno $(p<0,05)$, izuzimajući učenike s dovoljnom ocjenom. Kod učenika koji su imali ocjenu dovoljan zabilježena je smanjena dosada na nastavi, ali to smanjenje nije statistički značajno $(p=0,066)$. Nalazi prosječnih vrijednosti pokazuju da su dovoljni učenici napravili najveći pomak, što nameće zaključak da je upravo tim učenicima način izvođenja nastave najvažniji jer je kod njih razina dosade najviše primijećena. Ovdje bi bilo važno ispitati utječe li upravo način rada s učenicima na njihov slabi uspjeh. Dokaz za ovu tvrdnju pomogao bi mnogim učiteljima da riješe slabu motivaciju i dosadu slabih učenika, a time i njihov slabiji uspjeh.

Rezultati kontrolne grupe potvrđuju da klasična nastava povećava dosadu kod učenika bez obzira na njihovu školsku ocjenu skoro podjednako u svim ispitivanim grupama.

Sve navedene konstatacije govore u prilog potvrdi treće hipoteze o pozitivnom utjecaju eksperimentalnoga modela na učenike bez obzira na ocjenu iz Engleskoga jezika.

Emocionalne reakcije učenika u jakoj su vezi s procesom učenja, odnosno njegovim ishodima i rezultatima tako da emocionalne reakcije radoznalosti, oduševljenja i radosti doprinose uspjehu, dok naprotiv negativne emocionalne reakcije učenika doprinose neuspjehu. Pozitivne emocije u nastavi treba svakako iskoristiti jer djeluju na uspješno rješavanje različitih nastavnih problema, aktiviraju misaone procese višega reda te značajno utječu na kreativnost (Rijavec, Miljković, Brdar, 2008). Tako se uspješnom 
nastavom smatra ona nastava koja će kod učenika izazvati ugodu i radost te ona nastava koja odgovara potrebama učenika za osobnim rastom i razvojem (Bognar, Kragulj, 2009).

\section{Zaključak}

Obrazovanje je jedan od ključnih faktora u životu svakog pojedinca. Bez kvalitetnoga obrazovanja nema ni kvalitetnoga društva. Stremljenje kvalitetnom obrazovanju zahtijeva zanimljivu i efikasnu nastavu, koja je kamen temeljac uspješnosti.

Kao i odrasli, tako i učenici s više volje i zadovoljstva, poleta i elana rade ono što ih zanima i što im je zanimljivo, što vrijedi i u nastavnom procesu.

Kada govorimo o uspješnoj nastavi, neizbježno je naglasiti važnost kreativnosti kod učenika.

Monotonija, jednoličnost vode dosadi u nastavi, a dosada sputava i guši učeničku volju i želju za radom, a time i nemogućnost kreativnoga djelovanja.

Nalazi istraživanja pokazali su i da kreativni model nastave smanjuje dosadu u nastavi općenito, ali i kod učenika bez obzira na spol i ocjenu iz nastavnoga predmeta. Što je kreativnost na višem stupnju, manja je mogućnost pojave dosade u nastavi. Postoji nekoliko ograničenja studije. Jedno od ograničenja je da je istraživanje provedeno s učenicima razredne nastave, potrebno je istraživanje provesti is učenicima viših razreda osnovne škole, odnosno učenicima u predmetnoj nastavi kako bi se vidjeli učinci eksperimentalnoga modela. Ograničenje studije je i u tome što eksperimentalni model nije primijenjen i kod drugih nastavnih predmeta tako da se dobiveni nalazi mogu testirati samo na nastavi Engleskoga jezika. 